\title{
Plant Health and Security in the Age of Genomics: Our Roles as Scientists and as a Scientific Society
}

\author{
Jacqueline Fletcher
}

Department of Entomology and Plant Pathology, Oklahoma State University, 127 Noble Research Center, Stillwater 74074.

When I first began, three years ago, to think about a theme for this meeting, I wanted to choose a topic that would touch every plant pathologist in this hall. At that time, the story that demanded to be told was that of genomics, a technology that has revolutionized our science and redirected our thinking about the relationships between plants and pathogens, but our familiar world and its priorities changed in September 2001. Soon, guided by the APS Strategic Plan, our society (represented by the Public Policy Board and assisted by Kellye Eversole, our Washington liaison) stepped up to assist our nation by spreading the awareness and knowledge of plant pathology and plant protection to federal agencies and policy makers. Biosecurity was not just a by-word; it was a part of our mission. Recently, as I returned to the responsibility of choosing a meeting theme, I was torn between the issues of genomics and those of biosecurity until I realized that the two were in many ways inseparable. I hope that by the end of this presentation you will agree with me.

Let me turn first to the science of genomics, a technology that holds great promise. Some of us already know what benefits genomics can offer; a number of us already work directly in genomics research. Others may not have had an opportunity to see how genomics can make our lives and work easier or better. Our speakers today have addressed the power of genomics as it can be applied in each of the research arenas we represent. They have shown us how this new technology can reveal the content and reorganization of the genomes of both plant pathogens and their plant hosts. They have described how functional genomics will tell us the roles of many of these genes; this knowledge will not only help us understand the relationships between phytopathogens and their hosts, but also will open doors for deployment of their genes for beneficial purposes. In a practical sense, our speakers have painted the mental picture of a future in which genomics will help us rapidly detect pathogens and diagnose diseases, silence undesirable genes and turn on beneficial ones, develop diseaseand stress-resistant crops, engineer beneficial plant products, and design more effective research strategies.

The positive attributes of genomics do not come without concerns however. Ethical issues, the potential for unintended harmful outcomes or side effects and privacy issues related to the identification of certain genes are just some of the concerns voiced not only by the public, but also by scientists.

What is an appropriate role for any professional society, and more specifically, for The American Phytopathological Society, in the development and application of new technologies with such potential for both good and harm? In the late 1990s, with clear support from APS members, the APS Public Policy Board (PPB) identified the support of genomics funding and application as one

Publication no. P-2003-1110-010 of its major focus areas. At the 2000 APS Annual Meeting, a symposium on "Microbial Genome Sequencing" informed members of the status of the technology as well as its potential applications and possible problems, and to begin to set criteria and priorities for sequencing of plant pathogens of critical importance. Input from APS members was collected at the symposium, as well as from various subject matter committee meetings and informal conversations. Additional input was gathered from committee chairs after the meeting, and an APS White Paper, "Microbial Genomic Sequencing Perspectives of The American Phytopathological Society," was released (available online at APSnet).

In the spring of 2001, an APS-sponsored workshop, "Genomic Analysis of Plant-Associated Microbes," was funded jointly by grants from the U.S. Department of Agriculture, the National Science Foundation, and the Department of Energy. The workshop, moderated by PPB members Jan Leach and Scott Gold, brought together representatives from these and other U.S. sciencebased government agencies, academia, and private companies, as well as members of the international microbial community. The goals of the group were to assess the status, set priorities, and determine future needs related to microbial genome sequencing. The conclusions of this workshop were presented in a second APS White Paper, "A Plant-Associated Microbe Genome Initiative" (available online at APSnet).

Among the recommendations in the paper was a proposal for a 5-year \$500 million international initiative for sequencing priority microorganisms. Significant outcomes included greater appreciation by funding agencies for the importance of plant pathogens as sequencing candidates and the creation of new funding programs; proposals for sequencing plant pathogens are now being funded at significantly higher levels, and agencies are using APS input on pathogen prioritization. We have seen a significant number of pathogen sequences being completed and made publicly available. Public information sessions, required near the completion of sequencing projects by most of the funding programs, are being held-some even scheduled at APS Annual Meetings, where the audience is often much broader than would otherwise be the case-to share sequence information with the scientific community.

In the fall of 2001 our world changed. As Rita Colwell put it in an article in ASM News (1), "The events of September 11 have ...opened the box of the unimaginable and released the unthinkable." However, Colwell noted, just as the Chinese symbol for the word "crisis" is composed of the characters for both danger and opportunity, this terrorist event triggered both negative and positive responses. Direct negative impacts include the threat of economic or social loss from bioterror events. Indirect negative impacts are just as troubling. These include new regulations and new restrictions on the practices of research and scientific communication, the loss of privacy that accompanied 
the imposition of background checks and other clearances for certain types of research, and hindrances to international collaboration and global communication. On the other hand, positive impacts were seen as a result of greater appreciation in Washington for the needs of plant health and security in the United States. This new perspective on the importance of plant pathogens and pests led to the development of a National Plant Diagnostic Network, greater support for microbial genomics research (due to its relevance to detection, diagnostics, and forensics), and more effective communication among scientists and government agencies. New and rejuvenated alliances developed between federal, state, and local agencies, professional societies, and the private sector.

During this time, APS leaders had to decide what our society could, and should, do to help address critical national needs. Using the APS Strategic Plan as a guide, some responsibilities seemed appropriate and important: (i) serve as a source of unbiased, reliable, and science-based information to policy makers, the public, other scientists, and each other; (ii) help communicate new national policies to our APS members, and (iii) promote responsible stewardship of the practice and beneficial applications of plant pathology and deter the misuse of tools, organisms, or information.

Soon after 9-11, APS formed two ad hoc committees to guide the society's activities in this area: Crop Biosecurity (chaired initially by Jim Cook and later by Larry Madden; this committee has since been adopted as a standing committee) and Emerging Diseases and Pathogens (chaired by Doug Luster). These committees worked in concert with, and complementary to, the APS PPB. APS took on a greater presence in Washington as our nation grappled with science-related issues and policy development related to biosecurity.

It is often difficult to precisely measure the impacts of activities in the political arena, but it is clear that APS has made a difference over the past two years. The PPB has had a significant voice in biosecurity communications at the national level, and APS has become recognized as a reliable science-based resource for issues related to plant health. Our first major event, in March 2002, was an APS-hosted Congressional Briefing to inform congressional staff members, agency representatives, and the news media about threats related to plant pathogens, the resources available in our profession and our society, and what we felt were critical gaps in our preparedness. An APS Biosecurity White Paper, "The American Phytopathological Society: The First Line of Defense," developed for use at the Briefing, may be viewed on the APSnet website. In it, APS recommends (i) new investments in research, particularly in genomics, diagnostics, and epidemiology, (ii) new investments in infrastructure, including a national network of diagnostic laboratories and a national center for coordination of plant-related biosecurity activities, and (iii) new investments in training, particularly for first detectors, graduate students, and diagnosticians. Positive impacts of the Briefing, strengthened by PPB follow up visits to agency offices, were apparent as increased funding for plant pathogen genomics, with APS input on prioritization of pathogens for sequencing, the development by the USDA of the National Plant Diagnostic Network, and the consideration, at many levels, of APS's recommendation for a national center for coordination of plant biosecurity activities. In addition, APS assisted APHIS in the development of reasonable and effective lists of plant pathogens for regulation and participated in a workshop sponsored by the National Academy of Sciences on "Scientific Openness and National Security," after which the APS Publications Board reexamined its guidelines in light of new concerns.

In March 2003, APS was awarded funds from the USDA (APHIS, ARS, and CSREES) for the development of a workshop in Washington D.C. to assess progress in meeting the nation's needs in the area of plant biosecurity. Planned by the APS PPB, and chaired by PPB Director John Sherwood, the workshop again gathered representatives of government departments, offices and agencies, academia, and the private sector. The recommendations of this event were presented in the second of APS's biosecurityrelated White Papers, "Crop Biosecurity: Are We Prepared?" (available online at APSnet). Among them was a reiteration of the need for a national coordinating center for efforts in plant health.

Among the speakers at the March workshop was a representative of the Department of Homeland Security's Directorate of Science and Technology, Office of Bio Countermeasures Coordination. This unit is charged to coordinate all of the nation's efforts in biosecurity, including those directed toward humans, animals, and plants. Because there is currently no central national coordinating entity for biosecurity efforts for plants, the Department of Homeland Security supported our concept of a national center for plant biosecurity and funded a workshop, "National Center for Crop Biosecurity," in Washington, D.C. in July 2003, where representatives from relevant agencies, offices, private entities, and scientific societies came together to plan for a unit that would enhance communications and coordination among all groups involved in plant biosecurity. The draft Center proposal, which was circulated to all APS members prior to the workshop, is now in revision based on input from both APS members and workshop attendees, who will have another chance for input before the proposal is sent forward to the Department of Homeland Security.

I want to return now to my original question: how do genomics and biosecurity interface? Our individual research, teaching and outreach activities, as well as the discipline of plant pathology and APS are being shaped both by genomics technologies and by national security concerns. On one hand, genomics offers promise for technical advances in both plant health and security. On the other, biosecurity initiatives may bring critically needed visibility, appreciation, and funding to genomics and other plant pathology issues.

What can and should APS's role be in these national priorities? First, we can be an important vehicle for two-way communication. Scientific societies can serve as a source of reliable, unbiased science-based information related to plant pathogens and diseases. APS accomplishes this through our high-quality journals and books, our annual and divisional meetings, and through PPB activities such as personal visits to federal agencies, letters, and responses to the Federal Register and release of white papers or policy statements. The PPB also provides communication in the other direction, bringing timely and relevant information about policy development issues to our members. A second role for APS, and one of our society's strengths, lies in education and training activities. The APSnet Education Center is an outstanding model for dissemination of educational materials related to plant pathology and plant health. We also host teaching-based sessions at our annual and divisional meetings and short courses and workshops between meetings. These types of activities have expanded in the past couple of years to highlight both genomics and biosecurity. Finally, APS should and does promote responsible stewardship within our discipline. We do this through the strong ethical principles of our members, which are highlighted in the APS Code of Professional Ethics, the APS Position Statement on Biological Weapons, the Policy Guidelines of the APS Publications Board, and the many other statements our society has formulated to set an impeccable standard and expectation for all of us.

Thirty-three years ago, Nobel Peace Laureate Norman Borlaug said "Food is the cornerstone of national security." I believe he was right about this. Many of you have faced new and difficult challenges as a result of recent world events, but plant pathologists are a critical element in a food-secure nation, and APS and its members are stepping up to the plate.

\section{LITERATURE CITED}

1. Colwell, R. R. 2002. Microbiologists in an age of terrorism. ASM News 68:586-587. 